\title{
MORAL SI PENERUS BANGSA
}

Oleh :

Agnes Nona Lorenza

UNIKA Widya Mandala Madiun

\begin{abstract}
ABSTRAK
Kilas balik dengan kejadian-kejadian di sekitar tentang bagaimana sikap, sifat, dan attitude dari anak muda zaman sekarang. Banyak kasus yang terjadi dan menjadi viral tentang bagaimana tingkah laku anak muda zaman sekarang di mana ini adalah tindakan yang negatif. Bukannya merasa malu atau menunjukkan rasa bersalahnya, tapi mereka justru bangga akan apa yang telah diperbuatnya. Banyak kasus tentang hilangnya moral anak muda yang telah viral, lalu bagaimana yang tidak viral? Tak terhitung banyaknya barangkali. Apakah yang mereka pikirkan saat melakukan hal-hal yang menyalahi etika? Mengapa mereka terlihat baik-baik saja saat dan setelah melakukan hal negatif yang merugikan orang lain tersebut?
\end{abstract}

\section{A. Pendahuluan}

Secara etimologis etika berasal dari bahasa Yunani ethos, berarti kebiasaan yang berkaitan dengan tindakan/tingkah laku manusia. Ethos memiliki makna “anaction that is one's own”, berarti suatu tindakan yang dilakukan seseorang dan menjadi miliknya. Sedangkan dalam bahasa Latin ada kata mores, yang darinya kata moral diturunkan. Dengan demikian "ethical dan moral" merupakan suatu sinonim. Singkat kata, etika merupakan tindakan yang mengantar orang pada bagaimana menjadi baik (Dewantara A.W, Filsafat Moral, 2017). 


\section{B. Pembahasan :}

Ditinjau dari makna kata "etika" yang berarti tindakan yang seharusnya mengantarkan orang kepada kebaikan. Etika atau moral telah ada sejak dahulu kala, namun pelaksanaannya kian hari kian memudar dan akhirnya ditinggalkan oleh sebagian orang. Miris memang jika membahas tentang etika di zaman sekarang. Banyak kasus terjadi dengan mempertaruhkan etika para pelakunya. Kasus sederhana yang marak terjadi dikalangan pelajar adalah bully. Banyak sekali kasus yang mengatasnamakan pembullyan, bahkan dari pengalaman pribadi saya kasus bully pernah juga saya alami pada masa SD. Memang tidak seburuk apa yang dilakukan anak sekolah menengah di zaman ini, tapi apakah pengajaran etika di rumah dan di sekolah ter-terapkan? Mungkin bagi anak SD mengolok-olok adalah hal biasa, namun mereka tidak mengetahui bahwa masa buruk di saat kecillah yang menyebabkan beragam trauma dan perubahan persepsi serta kepribadian anak-anak.

Banyak orang tidak menyadari akan hal ini, tapi inilah yang saya rasakan, atau mungkin memang tidak banyak anak yang seperti saya, saya pun tak bisa men-judge mereka. Tapi lihat dan amatilah kasus lain, seperti seorang anak yang membunuh orang tua dan keluarganya sendiri misalnya. Apakah itu salah orang tua karena tidak mengajarakan moral? Bagi saya itu bukanlah kesalahan orang tua ataupun orang lain, namun adalah kesalahan individu itu sendiri. Mengapa demikian? "Karena etika memiliki karakter normatif yang berarti refleksi etika tunduk pada prinsip-prinsip akal budi yang sehat dan benar (Dewantara A.W, Filsafat Moral, 2017)”.

Dengan demikian jelas bahwa penurunan etika anak zaman sekarang adalah karena prinsip akal budi mereka yang bermasalah atau akal budi mereka yang tidak sehat. Hal yang marak terjadi saat ini adalah seks bebas, yang menurut mereka adalah hal biasa dan lazim dilakukan. Amazing!!! Melakukan hal intim di luar nikah bagi mereka biasa saja dan seolah adalah hal yang wajib mereka lakukan. Apakah seperti ini seharusnya? Bukankah hal ini adalah suatu hal yang menunjukkan tidak dipikirkannya moral? Secara 
empiris "aktivitas seks di luar nikah sudah ketinggalan zaman jika dipandang sebagai pelanggaran norma-norma moral. Disebut empiris karena terlalu seringnya masyarakat menemui kejadian seperti ini (Dewantara A.W, Filsafat Moral, 2017)"'.

Jika dipikirkan kembali dan direnungkan, inikah kemajuan IPTEK? Dengan semakin canggihnya teknologi dan komunikasi di era saat ini, bukannya anak-anak semakin baik dalam meningkatkan mutu pendidikan mereka tapi malah membuat IPTEK menjadi suatu hal yang membuat mereka lebih mudah dalam menghujat satu sama lain. Perang komentar-komentar pedas marak terjadi di sosial media sekarang ini. Melakukan kebaikan lalu diposting di sosmed, ada yang menganggapnya sok baik, cari muka, dan lainlain. Padahal tidak semua orang memposting kegiatan baik mereka untuk pamer dan cari perhatian. Ada yang memang benar-benar tulus melakukannya. Namun, kebanyakan nitizen yang notabene-nya adalah haters selalu saja menghujat dan mengata-ngatai.

Bukannya membela atau berpihak, tapi alangkah baiknya jika semua kebaikan yang berusaha dibagi oleh orang lain selayaknya dihargai. Jangan selalu dicela sebagai pencari sensasi. Tulus atau tidaknya seseorang dalam membantu orang lain biarlah Tuhan saja yang mengetahui dan menghakimi. Kita sebagai sesama manusia semestinya mendukung perbuatan-perbuatan baik orang lain.

Hal semacam ini biarlah hati nurani masing-masing orang saja yang berkehendak. Iklas, tulus atau tidaknya perbuatan mereka, hati nuraninyalah yang menyaring. Segala perbuatan yang dilakukan individu itu berdasarkan pada hati nuraninya masing-masing. Dengan hati nuranilah setiap orang mempertimbangkan perbuatannya. Hati nurani berarti hati manusia memiliki semacam pertimbangan yang akan membimbing kehendak yang akan kita lakukan (Dewantara A.W, Filsafat Moral, 2017).

Anak muda adalah generasi penerus bangsa, jika banyak hal yang menyalahi etika dan telah terjadi sebanyak ini bagaimanakah ke depannya? Tidak semua memang, tapi apakah seperti ini penerus bangsa seharusnya? 
Daripada hanya belajar akademik dengan paras cantik/tampan yang di kedepankan, lebih baik belajarlah moral dengan baik dahulu. Apa gunanya jika cantik, tampan, pintar, berbakat tapi NOL BESAR dalam ETIKA.

Seringkali terdengar perkataan "Percuma cantik/ganteng tapi gak punya moral" atau "Pinter sih, tapi kok gak punya etika". Seperti tidak asing lagi dengan pernyataan tersebut. Tapi, apakah yang berbicara seperti itu sudah menerapkan dengan baik etika nya? Apakah dia sudah sangat paham benar tentang norma-norma yang ada dan melakukannya? Menghujat orang, apakah itu sudah termasuk etika baik? Memang kebanyakan dari kita termasuk saya sendiri pun sering melakukan hal ini. Menjadi komentator hidup orang lain, namun selagi komentar itu dapat membuat si pelaku menjadi sadar akan perbuatannya, kemungkinan itu tidak masalah. Dan baiklah bila komentar yang diberikan adalah hal yang membangun dan dapat menyadarkan si pelaku tadi. Manusia tidaklah luput dari kesalahan tapi alangkah baiknya jika saling mengingatkan dan menerima dengan terbuka segala kritikan yang terlontar.

Perkataan "Percuma cantik/ganteng tapi gak punya moral" atau "Pinter sih, tapi kok gak punya etika" memang telah banyak terjadi di masa kini. Dan kenyataannya banyak anak muda yang seperti itu. Mereka lebih mengedepankan berbagai cara agar mendapat kesenangan dan kepuasan tanpa memperdulikan etika dan norma yang berlaku di lingkungannya.

Saat banyak perkataan yang mempertanyakan tentang di manakah letak etika mereka, apakah hati nurani mereka merasa terusik? Jika mereka hanya menganggap itu sambil lalu, bisa jadi mereka sudah tidak peduli akan kritikan mengenai perbuatan mereka yang salah.

Banyak orang mengabaikan tentang etika saat ini. Mereka akan mengambil sambil lalu saja dengan hal-hal yang berbau etika. Entah karena sengaja, tidak sengaja, atau pun tidak peduli sama sekali. Cobalah amati sekitar, apakah di sekitar kita krisis moral sudah terjadi, atau masih dalam proses penurunan? Kebanyakan pengabaian moral terjadi di kalangan kota- 
kota besar, tapi tidak menutup kemungkinan akan terjadi pula pada daerahdaerah terpencil di dalam bangsa ini.

Dengan adanya kemajuan dalam bidang teknologi informasi dan komunikasi yang dapat diakses dengan sangat mudah oleh hampir semua orang, budaya acuh tak acuh yang sedang marak terjadi di kota-kota besar dapat mudah tersebar dan ditiru oleh masyarakat terlebih anak-anak muda yang berada di lokasi yang masih kental akan etika. Bahkan anak yang masih duduk di sekolah dasar pun dapat meniru hal yang menekankan penurunan etika ini.

Apalagi dengan kebanyakan orang tua yang di zaman ini terlalu sibuk bekerja dan tidak bisa selalu mendampingi anaknya. Kemungkinan penanaman moral akan semakin berkurang terhadap anak-anak. Namun, kembali lagi pada perihal karakter dari etika. Orang tua tidak sepenuhnya bersalah karena kesibukannya, karena jika si anak ini sudah beranjak remaja, seharusnya mereka bisa menggunakan rasio nya untuk memberikan pemikiran baik-buruk hal yang akan terjadi jika dia berbuat demikian. Dan hati nurani mereka juga akan berperan dengan memberikan pertimbanganpertimbangan akan resiko dan hasil yang akan didapat setelah melakukan sesuatu hal.

Inilah keadaan moral anak muda dalam bangsa kita. Banyak yang telah mengabaikan adanya moral dalam kehidupannya. Mereka berpikir mungkin etika tidaklah terlalu penting dalam menjalani kehidupannya. Mungkin pula mereka berpikir bahwa etika hanyalah suatu hal yang merepotkan dan membuat segala hal menjadi lebih rumit. Tapi pada kenyataannya, etika adalah hal yang sangat digunakan dalam kehidupan. Segala hal yang dilakukan tidaklah lepas dari etika. Apapun yang akan diperbuat oleh setiap manusia pasti tidak lepas dari moral. Jika tidak dengan moral mereka melakukannya, akan ada komentar-komentar negatif yang menyertai perilaku tersebut. 
Lalu bagaimanakah caranya memperbaikinya? Salah satu cara sederhana adalah memulai dari diri sendiri, jika diri sendiri sudah beretika, maka dampak baik bisa terjadi pula bagi lingkungan di tempat kita berada. Jika kita menjunjung moral, maka secara tidak langsung orang pun akan membalas perbuatan kita dengan etika pula. Jika etika yang kita miliki baik, maka balasan yang kita dapat juga akan menjunjung etika pula.

\section{Kesimpulan :}

Penurunan etika atau moral anak muda penerus bangsa telah terjadi, banyak orang menganggap itu hal biasa dan membiarkan sambil lalu. Tapi, ini adalah suatu hal besar bila pelakunya hampir semua anak muda. Akal budi yang baik dan sehatlah yang membuat individu memiliki moral yang baik. Dan hati nuranilah yang menimbulkan perbuatan terjadi. Hati nurani adalah tempat penimbang kehendak yang akan dilakukan oleh setiap manusia. Jika mereka telah menganggap etika adalah hal yang tidak penting, maka akal budi individu tersebut sudah tidak sehat lagi. Banyak kasus pengabaian etika yang pelakunya adalah anak-anak sekolah. Perbaiki diri sendiri dan berikan dampak baik bagi lingkungan sekitar adalah cara yang sederhana untuk memperbaiki etika. Mulailah dengan diri sendiri dan lanjutkan dengan mempengaruhi yang lain.

\section{Saran :}

Utamakan etika, jangan hanya tampang dan kecerdasan semata. 


\section{Daftar Pustaka}

Dewantara, A. (2017). Filsafat Moral (Pergumulan Etis Keseharian Hidup Manusia).

Dewantara, A. (2017). Diskursus Filsafat Pancasila Dewasa Ini.

Dewantara, A. W. (2017). Alangkah hebatnya negara gotong royong: Indonesia dalam kacamata Soekarno. PT Kanisius. 